\title{
Effect of Dietary $\beta$-Mannanase Supplementation and Palm Kernel Meal Inclusion on Laying Performance and Egg Quality in 73 Weeks Old Hens
}

\author{
Jun Yeob Lee ${ }^{1}$, Sang Yun $\mathrm{Kim}^{2}$, Jae Hwan Lee ${ }^{2}$, Jeong Heon Lee ${ }^{3}$ and Sang Jip $\mathrm{Ohh}^{4 *}$ \\ ${ }^{1}$ National Institute of Animal Sciences, Suweon, 441-706, Korea, ${ }^{2}$ CTC Bio Inc, Seoul, 138-858, Korea, ${ }^{3}$ Hanil Feed Co, \\ Yongin, 446-930, Korea, ${ }^{4}$ College of Animal Life Sciences, Kangwon National University, Chuncheon, 200-701, Korea
}

\begin{abstract}
This study was conducted to evaluate the effect of dietary $\beta$-mannanase supplementation and palm kernel meal (PKM) inclusion (5\%) on laying performance, egg quality and nutrient utilizability of laying hens with 73 weeks of age. A total of 240 Lohmann brown laying hens with average $77.5 \%$ egg production were randomly allocated with 60 hens per treatment, 4 replicates per treatment and 15 hens per replicate. Experimental design was a completely randomized design with $2 \times 2$ factorial arrangement, with the factors being (1) two levels of PKM (0 vs. 5\%) and (2) with or without dietary $\beta$-mannanase $(480 \mathrm{IU} / \mathrm{kg}$ of diet CTCzyme $\left.^{\circledR}\right)$ supplementation. All hens were housed in cages $(35 \mathrm{cmW} \times 35 \mathrm{cmD} \times 40 \mathrm{cmH})$ with 2 hens per cage for six weeks feeding trial. Laying performance was recorded daily during feeding trial. Egg quality, nutrients utilizability and blood assays were done at the end of feeding trial. Egg production was improved $(\mathrm{P}<0.05)$ by both dietary PKM inclusion and $\beta$-mannanase combined supplementation. Either $\beta$-mannanase or PKM did not affect feed intakes and feed conversion ratio of all diets. Egg weight of hens fed diet containing $5 \%$ of PKM had heavier $(\mathrm{P}<0.05)$ eggs compared with hens fed without PKM. Albumen height was improved $(\mathrm{P}<0.05)$ by dietary mannanase supplementation. Crude fat utilization of $5 \%$ PKM diet was higher than that of no PKM diet regardless of $\beta$-mannanase supplementation. Both DM and total carbohydrate utilization were decreased $(\mathrm{P}<0.05)$ in hens fed $5 \%$ PKM diet. Serum IgG and yolk IgY contents of PKM groups were lower $(\mathrm{P}<0.05)$ than those of no PKM groups. This result showed that $5 \%$ PKM diet, independent of dietary $\beta$-mannanase supplementation, was able to improve egg production. In addition, dietary $\beta$-mannanase supplementation could be used for improving the albumen height of eggs.
\end{abstract}

(Key words : $\beta$-mannanase, 73 weeks old laying hen, Palm kernel meal, Laying performance, Egg quality)

\section{INTRODUCTION}

Old aged laying hens are known to consume less feed with increasing age (Pavlik et al., 2009), which has led to a decrease in egg production. Therefore, the egg production from the hens older than $65 \sim 70$ weeks has always been a serious challenge especially on economic stand point. Recently, the profit of egg production against the cost of feed became even worse due to the price hike of feed ingredients. The decrease in feed consumption and following decline in egg production in old aged hens could be attributed to the decreased metabolic rate in the old aged hens compare to young hens (Lin et al., 2006; Pereira et al., 2010). To recover the disadvantage of old aged hens, producers have sought the ways to reduce feed cost as well as to enhance metabolic efficiency in the old aged hens.

To reduce the cost of feed, inclusion of relatively cheaper ingredient such as palm kernel meal (PKM) has been proposed. PKM contains average $14 \sim 16 \% \mathrm{CP}$ and 1,600 $1,700 \mathrm{kcal} \mathrm{ME}$, for chickens. But the PKM also contains 35 $\sim 40 \%$ mannans, which is poorly digestible by poultry (Sundu et al., 2006). Therefore, supplementation of its respective enzyme, mannanase has been recommended $(\mathrm{Wu}$ et al., 2005; Sundu et al., 2006). In addition, several poultry studies (Sundu et al., 2006; Chong et al., 2008; Zanu et al., 2012) showed that the appropriate level of PKM inclusion had encouraged the feed intake in laying hens. Therefore, it was hypothesized that the PKM might act as a stimulator of feed intake in the old aged hens.

However, little information is known how dietary PKM inclusion and mannanase supplementation could affect old aged laying hens in terms of egg production performance, nutrient utilization and egg quality parameters. Therefore, this study was conducted to investigate the effect of $\beta$-mannanase supplementation to PKM included diet on laying performance, egg and shell quality, nutrients utilization and

* Corresponding author: Sang Jip Ohh, College of Animal Life Sciences, Kangwon National University, Chuncheon, Korea. E-mail: sjohh@kangwon.ac.k 
immune response in old aged laying hens.

\section{MATERIALS AND METHODS}

The protocols for feeding trials, nutrients utilization assay and blood collection methods were approved by the Institutional Animal Care and Use Committee of Kangwon National University, Chuncheon, Korea.

\section{Experimental laying hens and care of the birds}

A total of 240 Lohmann brown laying hens of 73 weeks of age with average $77.5 \%$ egg production were randomly allocated into 4 treatments with 4 replicates per treatment and 15 hens per replicate. The 4 treatments were arranged in a $2 \times 2$ factorial design with two levels (0 IU vs. $480 \mathrm{IU} /$ $\mathrm{kg}$ of diet) of dietary $\beta$-mannanase and two levels (No vs $5 \%$ ) of dietary palm kernel meal (PKM) inclusion. $\beta$ mannanase used in this study was CTCzyme ${ }^{(C T C B i o ~ I n c ., ~}$ Korea) containing 800,000 unit $\beta$-mannanase $/ \mathrm{kg}$ supplement. All the birds were allocated to 2 floor straight type steel wire laying hen cages with 2 hens per each cage room (35 $\mathrm{cmW} \times 35 \mathrm{cmD} \times 40 \mathrm{cmH}$ ) for six weeks. At the end of feeding trial, 5 laying hens with similar body weight and egg production were chosen from each treatment. Totally, 20 laying hens were individually housed on A-type steel wire laying hen cage for nutrient utilization assay. After 5 days of acclimatization, $100 \mathrm{~g}$ of each experimental diet was offered to each hen per day for 3 consecutive days. At the first and the last day, daily feeds were mixed with $0.3 \%$ ferric oxide as a marker for fecal collection.

The 15L: 9D (15lux $/ \mathrm{m}^{2}$ of illumination) lighting program was implemented throughout the feeding and nutrient utilization trials. Temperature and relative humidity of hen house were maintained at $24 \sim 27^{\circ} \mathrm{C}$ and $70 \sim 75 \%$, respectively. All laying hens were vaccinated according to the conventional vaccination program. The experimental hens were debeaked in the early age of life.

During 6 weeks feeding trial, both feed and water were offered ad libitum. Feed was offered on plastic straight groove feeder and water was supplied by water nipple. Experimental diets were formulated to be iso-nitrogenous (16.2\% CP) and iso-caloric (2,720 kcal ME/kg of diet). Corn, soybean meal (44\%) and rice bran were the major ingredients although synthetic amino acids were employed to meet the amino acid requirement (Lohmann Brown Management Guide,
2007. Lohmann GB Ltd, UK). Palm kernel meal (PKM) used in this experiment was imported from South Asia, and then purchased from local feed mill in Korea. Formula and nutrients composition of experimental diets are shown in Table 1.

\section{Measured items and analyses}

Egg production was recorded daily at 09:00 $\mathrm{h}$ then egg weight and mortality were also recorded daily. Hen day egg production (HDEP), average daily feed intake (ADFI), feed conversion ratio (FCR), and mortality were calculated weekly and at the end of feeding trial. For nutrient utilization assay, the fresh excreta were collected daily from the time of first appearance of colored excreta until the time just before the reappearance of colored excreta. Freshly collected excreta were dried in an electric oven with forced aeration at $65^{\circ} \mathrm{C}$ until reached to the constant weight. Whole dried excreta samples were pooled, weighed, and ground then kept at room temperature for further chemical analyses. Total feed intake per hen was recorded and representative feed samples were ground for chemical analyses.

Thirty eggs per replicate were randomly collected at wk 4 of feeding trial period for the analyses of egg quality parameters. Eggshell strength was measured using egg shell intensity tester (FHK, Fujihira Industry Co., LTD, Japan). Eggshell thickness was determined using a dial pipe gauge according to the procedure (Monira et al., 2003). Albumen height was measured using tripod micrometer. Egg yolk color score was examined using the Roche 15-point color fan.

All proximate components (DM, CP, energy, ash and fat) in both excreta and diet samples were analyzed according to the standard methods of AOAC (2005). Nutrient utilization was calculated by subtracting amounts of nutrient in excreta from the amount of nutrients in consumed feed. To determine the concentration of IgY, the water-soluble fraction (WSF) of egg yolk was separated according to the methods described by Bizhanov et al. (2004), and the WSF was used to quantify IgY concentration by the protocol of ELISA kit (E30-104) as described by Lee et al. (2002) using ELISA reader (Power Wave XS, BioTek, USA). The concentration of IgY and standard antibody were measured at absorbance of $450 \mathrm{~nm}$, and the test repeated three times and the mean values of optical density were obtained. Each sample was tested in triplicate and the IgY content of egg yolk was 
Table 1. Formula and chemical composition of experimental feeds

\begin{tabular}{|c|c|c|c|c|c|}
\hline \multirow[b]{2}{*}{$\beta$-mannanase } & \multirow[t]{2}{*}{ PKM } & \multicolumn{2}{|c|}{ No PKM } & \multicolumn{2}{|c|}{$5 \%$ PKM } \\
\hline & & $0 \mathrm{IU}$ & $480 \mathrm{IU}$ & $0 \mathrm{IU}$ & $480 \mathrm{IU}$ \\
\hline \multicolumn{6}{|l|}{ Ingredients, \% } \\
\hline Corn & & 52.15 & 52.15 & 48.10 & 48.10 \\
\hline Soybean meal (44\%) & & 18.00 & 18.00 & 17.05 & 17.05 \\
\hline Corn gluten & & 0.50 & 0.50 & 0.50 & 0.50 \\
\hline Meat and bone meal & & 4.55 & 4.55 & 4.55 & 4.55 \\
\hline Rice bran & & 10.16 & 10.16 & 10.16 & 10.16 \\
\hline Rapeseed meal & & 2.00 & 2.00 & 2.00 & 2.00 \\
\hline PKM & & 0.00 & 0.00 & 5.00 & 5.00 \\
\hline DDGS & & 2.00 & 2.00 & 2.00 & 2.00 \\
\hline Tallow & & 1.00 & 1.00 & 1.00 & 1.00 \\
\hline Lysine $(78 \%)$ & & 0.11 & 0.11 & 0.11 & 0.11 \\
\hline Methionine $(100 \%)$ & & 0.19 & 0.19 & 0.19 & 0.19 \\
\hline Dicalcium phosphate & & 0.34 & 0.34 & 0.34 & 0.34 \\
\hline Limestone & & 8.20 & 8.20 & 8.20 & 8.20 \\
\hline Salt & & 0.29 & 0.29 & 0.29 & 0.29 \\
\hline Sodium carbonate & & 0.01 & 0.01 & 0.01 & 0.01 \\
\hline Choline chloride & & 0.08 & 0.08 & 0.08 & 0.08 \\
\hline Antioxidant & & 0.01 & 0.01 & 0.01 & 0.01 \\
\hline Vit. Mix. ${ }^{1)}$ & & 0.03 & 0.03 & 0.03 & 0.03 \\
\hline Min. Mix. ${ }^{2)}$ & & 0.15 & 0.15 & 0.15 & 0.15 \\
\hline Phytase & & 0.03 & 0.03 & 0.03 & 0.03 \\
\hline Toxin binder & & 0.20 & 0.20 & 0.20 & 0.20 \\
\hline$\beta$-mannanase, IU $/ \mathrm{kg}^{3)}$ & & 0 & 480 & 0 & 480 \\
\hline Total & & 100.00 & 100.00 & 100.00 & 100.00 \\
\hline \multicolumn{6}{|c|}{ Chemical composition, calculated } \\
\hline C. Protein, $\%$ & & 16.20 & 16.20 & 16.20 & 16.20 \\
\hline C. Fat, $\%$ & & 4.50 & 4.50 & 4.50 & 4.50 \\
\hline C. Fiber, \% & & 3.60 & 3.60 & 3.60 & 3.60 \\
\hline C. Ash, \% & & 15.70 & 15.70 & 15.70 & 15.70 \\
\hline $\mathrm{Ca}, \%$ & & 4.00 & 4.00 & 4.00 & 4.00 \\
\hline Total P, \% & & 1.20 & 1.20 & 1.20 & 1.20 \\
\hline Available P, \% & & 1.00 & 1.00 & 1.00 & 1.00 \\
\hline $\mathrm{ME}, \mathrm{kcal} / \mathrm{kg}$ & & 2,720 & 2,720 & 2,720 & 2,720 \\
\hline
\end{tabular}

${ }^{1)}$ The vitamin premix contains the followings per $\mathrm{kg}$ of diet: Vit. A, $18.000 \mathrm{IU}$; vit. D3, $4.500 \mathrm{IU}$; vit. E, $31.5 \mathrm{IU}$; menadione, 3.6 $\mathrm{mg}$; thiamin, $1.8 \mathrm{mg}$ riboflavin, $4.8 \mathrm{mg}$; pyridoxine, $3.6 \mathrm{mg}$; cobalamin, $0.03 \mathrm{mg}$; niacin, $22.5 \mathrm{mg}$; panthothenic acid, $15 \mathrm{mg}$; folic acid, $0.45 \mathrm{mg}$.

${ }^{2)}$ The mineral premix contains the followings per $\mathrm{kg}$ of diet: $\mathrm{Mn}, 86.4 \mathrm{mg} ; \mathrm{Zn}, 72 \mathrm{mg}$; Fe, $74.6 \mathrm{mg} ; \mathrm{Cu}, 6 \mathrm{mg} ; \mathrm{I}, 1.5 \mathrm{mg} ; \mathrm{Co}, 0.288$ $\mathrm{mg}$; Se, $0.216 \mathrm{mg}$.

${ }^{3)}$ Mannanase: CTCzyme ${ }^{\circledR}$ (CTCBio Inc., Korea) containing 800,000 unit $\beta$-mannanase / kg supplement.

Abbreviations: PKM: Palm kernel meal, DDGS: Distillers dried grain and solubles, ME: Metabolizable energy.

expressed in $\mathrm{mg} / \mathrm{ml}$ of egg yolk. At the termination of vein using vacutainer tube. The tube was settled 30 minutes feeding trial, 6 hens $\vee$ representing average body weight and at room temperature, and then $\vee$ centrifuged at $1,500 \mathrm{~g}$ for 10 egg production were selected from each treatment then fasted minutes. Top liquid portion was collected as serum, and then 24 hours. About $4 \mathrm{ml}$ of blood were collected from brachial stored in the freezer at $-70^{\circ} \mathrm{C}$ until analysis. Chicken $\operatorname{IgG}$ 
Lee et al.; Dietary ß-Mannanase and Palm Kernel Meal PKM in Old Aged Laying Hens

ELISA Quantitation Kit (Bethyl laboratories, Inc., U.S.A) was employed for IgG analysis by reading absorbance using ELISA reader (Power Wave XS, BioTek, USA).

All the data were analyzed by SAS program (SAS Institute Inc., 2004) using the General Linear Model (GLM) procedure of a factorial $\vee$ design. Mean values of each replicate were represented as an experimental unit and P-values were given and then statistically significant difference among treatments at $\mathrm{P}<0.05$ were expressed by different superscripts.

\section{RESULTS}

HDEP was improved by dietary PKM inclusion $(\mathrm{P}<0.05)$ as shown in Table 2. $\beta$-mannanase supplementation into PKM included diet tended $(\mathrm{P}=0.051)$ to improve the HDEP. However, there was no interaction effect by combination of $5 \%$ palm kernel meal inclusion and $\beta$-mannanase supplementation. Either $\beta$-mannanase or PKM did not affect feed intakes although the feed intake of mannanase supplemented 5\% PKM diet was numerically highest among all treatments. The highest feed intake of the mannanase supplemented 5\% PKM diet resulted in highest egg production in hens fed the diet. Although the feed conversion ratio (feed/egg) of hens fed no mannanase, 5\% PKM diet was lower $(\mathrm{P}<0.05)$ than that fed no mannanase, no PKM diet, there were no significant main effect from either PKM or mannanase. FCR of no mannanase, 5\% PKM diet was the most efficient compared to that of other three diets.

Egg weight of mannanase supplemented 5\% PKM group was significantly $(\mathrm{P}<0.05)$ heavier than that of other groups as shown in Table 3. Egg albumen height of egg from mannanase supplemented groups were higher $(\mathrm{P}=0.004)$ than those from no mannanase groups. The albumen height of eggs from no PKM, no mannanase group was $\operatorname{lower}(\mathrm{P}<$ 0.05) than that of other groups. There were no differences among treatments in egg shell thickness, egg shell strength and yolk color score.

Nutrients utilization of the experimental diets is shown in Table 4. DM, energy and total carbohydrate utilization of PKM diets were poorer $(\mathrm{P}<0.01)$ than those of no PKM diets. However, crude fat utilizations of PKM diets were higher $(\mathrm{P}<0.01)$ than those of no $\mathrm{PKM}$ diets, regardless of mannanase supplementation. Dietary mannanase supplementation

Table 2. Effect of dietary $\beta$-mannanase supplementation and palm kernel meal inclusion on egg production performance of old aged laying hens

\begin{tabular}{|c|c|c|c|c|c|c|c|c|}
\hline \multirow[b]{2}{*}{$\beta$-mannanase } & \multicolumn{2}{|c|}{ No PKM } & \multicolumn{2}{|c|}{$5 \%$ PKM } & \multirow[b]{2}{*}{$\mathrm{SE}$} & \multicolumn{3}{|c|}{ Main effect ( $\mathrm{P}$ values) } \\
\hline & $0 \mathrm{IU}$ & $480 \mathrm{IU}$ & $0 \mathrm{IU}$ & $480 \mathrm{IU}$ & & PKM & Mann & $\begin{array}{l}\text { PKM* }^{*} \\
\text { Mann }\end{array}$ \\
\hline Average daily feed intake (g/hen/day) & 108.37 & 109.99 & 108.23 & 115.60 & 5.67 & NS & NS & NS \\
\hline HDEP (\%) & $77.33^{\mathrm{b}}$ & $78.81^{\mathrm{b}}$ & $80.14^{\mathrm{ab}}$ & $83.37^{\mathrm{a}}$ & 2.49 & 0.004 & 0.051 & NS \\
\hline FCR (feed, g/egg, g) & 2.11 & 2.10 & 2.03 & 2.09 & 0.10 & NS & NS & NS \\
\hline
\end{tabular}

Abbreviations: PKM, palm kernel meal; HDEP, Hen day egg production; Mann, $\beta$-mannanase; SE, Standard error. FCR; Feed conversion ratio

${ }^{\mathrm{ab}}$ Mean values with different superscript within the same row differ significantly $(\mathrm{P}<0.05)$.

Table 3. Effect of dietary $\beta$-mannanase supplementation and palm kernel meal inclusion on egg and shell quality in old aged laying hens

\begin{tabular}{|c|c|c|c|c|c|c|c|c|}
\hline \multirow[b]{2}{*}{$\beta$-mannanase } & \multicolumn{2}{|c|}{0 PKM } & \multicolumn{2}{|c|}{$5 \%$ PKM } & \multirow[b]{2}{*}{ SE } & \multicolumn{3}{|c|}{ Main effects ( $\mathrm{P}$ values) } \\
\hline & $0 \mathrm{IU}$ & $480 \mathrm{IU}$ & $0 \mathrm{IU}$ & $480 \mathrm{IU}$ & & PKM & Mann & $\begin{array}{l}\mathrm{PKM}^{*} \\
\text { Mann }\end{array}$ \\
\hline Egg weight (g/egg) & $64.7^{\mathrm{b}}$ & $65.1^{\mathrm{b}}$ & $65.8^{\mathrm{b}}$ & $69.0^{\mathrm{a}}$ & 4.3 & 0.030 & NS & NS \\
\hline Egg shell strength $\left(\mathrm{kg} / \mathrm{cm}^{2}\right)$ & 2.76 & 2.40 & 2.45 & 2.53 & 0.67 & NS & NS & NS \\
\hline Albumen height $(\mathrm{mm})$ & $6.3^{\mathrm{b}}$ & $7.6^{\mathrm{a}}$ & $7.1^{\mathrm{a}}$ & $7.6^{\mathrm{a}}$ & 1.3 & NS & 0.004 & NS \\
\hline Yolk color score & 7.9 & 8.0 & 7.9 & 8.1 & 0.6 & NS & NS & NS \\
\hline Egg shell thickness $(\mu \mathrm{m})$ & 350 & 330 & 330 & 330 & 5 & NS & NS & NS \\
\hline
\end{tabular}

Abbreviations: PKM, palm kernel meal; SEM, Standard error; Mann, $\beta$-mannanase.

${ }^{\mathrm{ab}}$ Mean values with different superscript within the same row differ significantly $(\mathrm{P}<0.05)$. 
Lee et al.; Dietary ß-Mannanase and Palm Kernel Meal PKM in Old Aged Laying Hens

Table 4. Effect of dietary $\beta$-mannanase supplementation and palm kernel meal inclusion on nutrients utilization in old aged laying hens

\begin{tabular}{|c|c|c|c|c|c|c|c|c|c|}
\hline \multirow[b]{2}{*}{$\beta$-mannanase } & \multirow[t]{2}{*}{ PKM } & \multicolumn{2}{|c|}{ No PKM } & \multicolumn{2}{|c|}{$5 \% \mathrm{PKM}$} & \multirow[b]{2}{*}{ SE } & \multicolumn{3}{|c|}{ Main effects (P values) } \\
\hline & & $0 \mathrm{IU}$ & $480 \mathrm{IU}$ & $0 \mathrm{IU}$ & $480 \mathrm{IU}$ & & PKM & Mann & $\begin{array}{c}\text { PKM }^{*} \\
\text { Mann }\end{array}$ \\
\hline Dry matter & & $71.1^{\mathrm{a}}$ & $71.7^{\mathrm{a}}$ & $67.4^{\mathrm{b}}$ & $68.4^{\mathrm{b}}$ & 2.1 & 0.006 & NS & NS \\
\hline Crude protein & & 41.3 & 42.6 & 44.4 & 36.1 & 6.0 & NS & NS & NS \\
\hline Crude fat & & $83.9^{\mathrm{b}}$ & $85.1^{\mathrm{b}}$ & $89.1^{\mathrm{a}}$ & $89.9^{\mathrm{a}}$ & 2.6 & 0.003 & NS & NS \\
\hline Crude ash & & $36.6^{\mathrm{a}}$ & $25.4^{\mathrm{b}}$ & $35.6^{\mathrm{a}}$ & $18.5^{\mathrm{b}}$ & 6.2 & NS & 0.001 & NS \\
\hline Energy & & $74.8^{\mathrm{ab}}$ & $75.2^{\mathrm{a}}$ & $71.9^{\mathrm{b}}$ & $73.2^{\mathrm{ab}}$ & 1.9 & 0.021 & NS & NS \\
\hline Total-CHO & & $78.5^{\mathrm{a}}$ & $79.5^{\mathrm{a}}$ & $73.9^{\mathrm{b}}$ & $75.4^{\mathrm{b}}$ & 1.8 & 0.001 & NS & NS \\
\hline
\end{tabular}

Abbreviations: PKM, palm kernel meal; SE, Standard error; Mann, $\beta$-mannanase; CHO, Carbohydrates.

${ }^{\mathrm{ab}}$ Mean values with different superscript within the same row differ significantly $(\mathrm{P}<0.05)$.

Table 5. Effect of dietary $\beta$-mannanase supplementation and palm kernel meal inclusion on serum IgG and yolk IgY concentration in old aged laying hens

\begin{tabular}{|c|c|c|c|c|c|c|c|c|}
\hline \multirow[b]{2}{*}{$\beta$-mannanase } & \multicolumn{2}{|c|}{ No PKM } & \multicolumn{2}{|c|}{$5 \% \mathrm{PKM}$} & \multirow[b]{2}{*}{$\mathrm{SE}$} & \multicolumn{3}{|c|}{ Main effect (P values) } \\
\hline & $0 \mathrm{IU}$ & $480 \mathrm{IU}$ & $0 \mathrm{IU}$ & $480 \mathrm{IU}$ & & PKM & Mann & $\begin{array}{c}\text { PKM }^{*} \\
\text { Mann }\end{array}$ \\
\hline Serum IgG (mg/ml) & $10.65^{\mathrm{a}}$ & $11.29^{\mathrm{a}}$ & $10.57^{\mathrm{a}}$ & $8.10^{\mathrm{b}}$ & 1.98 & 0.057 & NS & 0.069 \\
\hline Yolk IgY (mg/ml) & $12.67^{\mathrm{ab}}$ & $13.04^{\mathrm{a}}$ & $10.52^{\mathrm{bc}}$ & $9.36^{\mathrm{c}}$ & 1.84 & 0.001 & NS & NS \\
\hline
\end{tabular}

Abbreviations: PKM, palm kernel meal; SE, Standard error; Mann, $\beta$-mannanase; Ig, Immunoglobulin.

${ }^{\mathrm{ab}}$ Mean values with different superscript within the same row differ significantly $(\mathrm{P}<0.05)$.

decreased $(\mathrm{P}<0.01)$ crude ash utilization compared to that of no mannanase groups. There was no interaction effect between PKM and mannanase on nutrients utilization.

Both serum IgG and yolk IgY concentrations tended to be affected $(\mathrm{P}=0.057)$ by dietary PKM inclusion as shown in Table 5. Both serum IgG and yolk IgY concentrations were the lowest $(\mathrm{P}<0.05)$ in mannanase supplemented PKM inclusion group. Contrastingly, the serum $\mathrm{IgG}$ and yolk $\operatorname{IgY}$ concentrations were the highest $(\mathrm{P}<0.05)$ in mannanase supplemented no PKM inclusion group. The higher concentrations in serum IgG proportionally exerted the higher concentrations in yolk IgY.

\section{DISCUSSION}

Egg production of old aged hens is known to be strongly associated with feed intake (Świątkiewicz et al., 2010; Catli et al., 2012). In this study, the highest HDEP in mannanase supplemented 5\% PKM diet was respectively associated with the highest feed intake of the diet. It is well known that feed intake of laying hen typically decreased after $50^{\text {th }}$ week (Pavlik et al., 2009) of age. Therefore, it is believed that the PKM inclusion contributed, in certain extent, for stimulating feed intake in this study. Several laying hen studies (Perez et al., 2000; Chong et al., 2008) reported increased feed intake by PKM inclusion in diets. However, there was a report (Zanu et al., 2012) which showed no difference in feed intake by dietary PKM inclusion.

It is still not proved what component in PKM could encourage the feed intake. Low water holding capacity and higher bulkiness of PKM were suggested as an accelerator of digesta passage and therefore, increased the feed intake (Sundu et al., 2006). Since the PKM inclusion level in this study was relatively low, it could be difficult to expect such a remarkable contribution to $\vee$ digesta passage. Medium to long chain $(\mathrm{C} 12 \sim \mathrm{C} 14)$ fatty acids in palm kernel oil has been suggested as a taste enhancer (Rahman et al., 2010). Dietary acids were also known to impart beneficial influence on egg production of $54 \sim 70$ week old hens (Soltan, 2008). Therefore, it is worth to behold the fact that the PKM typically contained $7 \sim 8 \%$ fat and about $50 \sim 60 \%$ of the fat are $\mathrm{C} 12 \sim \mathrm{C} 14$ fatty acids (Sahidi, 2005).

However, feed intake responses to the PKM diets in this study were bidirectional. There was no such an increase in feed intake when there was no simultaneous supplementation of mannanase. Non starch polysaccharides (NSP) including 
mannan was known to increase digesta viscosity and to reduce feed intake in poultry (Van Krimpen et al., 2011). It is typical that the PKM contained $40 \sim 45 \%$ and $28 \sim 32 \%$ of NSP and mannan respectively (Sundu et al., 2006). Once the dietary mannanase had hydrolyzed the mannan, however, the magnitude of viscosity increase would be negligible as shown in Mehri et al. (2010). In this case, the appetite stimulation by PKM could not be negated by viscosity problems. This could explain why there were the bidirectional responses against PKM diets.

Both PKM and mannanase could not significantly influence FCR although the FCR of no mannanase PKM diet was lowest among treatments, only better than that of no mannanase no PKM diet. Within the same PKM diets, higher intake of the mannanase supplemented PKM diet could be a cause of the slightly poorer FCR. In this study, the mannanase supplementation did not induce any significant impact on FCR. This could be explained by the relatively lower level of mannan in the final diet. If the amount of mannan is under any impact threshold level, the benefit by respective mannanase supplementation could be also negligible.

Both PKM inclusion and mannanase supplementation exerted heavier eggs than other diets. Egg weight is certainly depended upon sufficient and balanced feed intake ( $\mathrm{Li}$ et al., 2011). In this study, the heaviest egg weight was also observed in the group that had highest feed intake. There was a significant effect of PKM inclusion on egg weight and as previously confirmed in this study, the PKM acted as a feed intake stimulator. Dietary mannanase supplementation, regardless of PKM inclusion, increased egg albumen height. It is not clear how and why the mannanase was able to increase the albumen height. Albumen height typically depended upon feed quality and age of hens (Roberts and Ball, 2004). Poor quality fat and less available amino acids in PKM could be a cause of thinner albumen height. It is previously reported that poor quality protein and heat damaged amino acids decreased the height of egg albumen (Teleun et al., 2008). If the mannanase supplementation was able to improve the nutritional status of old aged hens, it could be postulated that the improved nutritional status could increase albumen height. Nevertheless, the average albumen height in this study was lower than typical albumen height of eggs laid at 70 weeks of age (Roberts and Ball, 2004).

There were no differences in egg shell quality due to either dietary mannanase or PKM inclusion. Shell quality including thickness and strength were known to decrease with age of hens, probably due to poorer functioning on calcium metabolism (Zita et al., 2012). Bone (Moreki et al., 2011) and serum calcium (Garlich et al., 1984) status that represent calcium metabolism were also diminished with increasing age. Therefore, replacement of poor quality calcium source with better source (Catli et al., 2012) and acidic modulation of gut by feed additives (Świątkiewicz et al., 2010; Hanafy, 2010) had improved the shell quality in old aged hens. In those studies, the egg production was also maintained well when the shell quality was maintained better than typical quality at those ages. But there was not such a kind of relationship in this study since the shell quality was not different among treatments. Either dietary mannanase or PKM did not influence the yolk color score in this study. It is well known that the yolk color is depended upon the characteristic of feed. In other study (Chong et al., 2008), PKM decreased the yolk color score with higher level (25\%) of supplementation, but no influence with lesser level (12.5\%) of supplementation. Therefore, substantially lower (5\%) level of PKM supplementation in this study could be a reason why the same PKM did not induce change in yolk color score.

PKM inclusion was not beneficial for improving the most of nutrients utilization. DM, energy and total carbohydrate utilization of no PKM diets were always higher than those of PKM diets. Poor utilization of the PKM diets could be attributed to NSP, which are poor in utilization in poultry digestive system (Meng et al., 2005). However, fat utilization was always higher in PKM diet compared to no PKM diet. PKM fat contained characteristically higher proportion of C12 C14 chain fatty acids (Atasie and Akinhanmi, 2009). It is also known that those fatty acids are relatively readily absorbable than other fatty acids (Ramirez et al., 2001; Ong and Goh, 2002). It is not clear why crude ash utilization was decreased by dietary mannanase supplementation. However, mannan induced changes in gut viscosity is believed to affect mineral absorption kinetics as shown in Van der Klis et al. (1995).

Humoral immune response of laying hen is known to be influenced by age of hen (Ebeid, 2011). In laying hens, yolk IgY concentration is strongly associated with transfer efficiency of serum IgG to IgY (Barua et al., 2000). Therefore, yolk IgY concentration is relatively higher in younger hens whereas serum $\operatorname{IgG}$ concentration is higher in older hens. This represents relatively more effective transfer metabolism in younger hens than older hens. Relatively 
Lee et al.; Dietary ß-Mannanase and Palm Kernel Meal PKM in Old Aged Laying Hens

lower IgY concentration in PKM groups could be attributed to the quality of PKM since it varied widely in quality (Sundu et al., 2006). It is known that the poor anti-oxidative status of old aged hens could be represented as poor immune status (Ebeid, 2011). Therefore, the immune response was stimulated by anti-oxidative diet such as omega-3 fatty acid in old aged laying hen(Ebeid, 2011). The mannanase did not induce any influence on humoral immune response of old aged hen in this study, which is similar to the result of other poultry studies ( $\mathrm{Li}$ et al., 2010; Zou et al., 2006). However, Zou et al. (2006) reported an increase of serum IgM by dietary mannanase supplementation. Therefore, the contradictory result could be attributed to either type of immunoglobulin or type of supplemental mannanase.

\section{IMPLICATIONS}

This result implied that a relatively cheaper ingredient, palm kernel meal could be successfully incorporated $(5 \%)$ to the diet of old aged laying hens. In addition, $\beta$-mannanase supplementation could be beneficial to increase the feed intake of palm kernel meal incorporated diet. Further, the increased feed intake evidently exerted an increased egg production in hens aged over 73 weeks. Therefore, this study showed that the performance of old aged laying hens could be improved by both dietary PKM by stimulating feed intake and the simultaneous supplementation of $\beta$-mannanase by alleviating anti-nutritional impact of mannans in the PKM.

\section{REFERENCES}

AOAC. 2005. Official Methods of Analysis (18th Ed). Asso. Off. Anal. Chem. Inc., Washington DC, USA.

Atasie, V. N. and Akinhanmi, T. F. 2009. Extraction, compositional studies and physico-chemical characteristics of palm kernel oil. Pak. J. Nutr. 8:800-803.

Barua, A., Furusawa, S. and Yoshimura, Y. 2000. Influence of aging and estrogen treatment on the IgY concentration in the egg yolk of chicken, Gallus domesticus. J. Poult. Sci. 37:280288.

Bizhanov, G., Jonauskiene, I. and Hau, J. 2004. A novel method, based on lithium sulfate precipitation for purification of chicken egg yolk immunoglobulin Y, applied to immunospecific antibodies against Sendai virus. Scan. J. Lab. Anim. Sci. 3:121-130.

Catli, A. U., Bozkurt, M., Kucukyılmaz, K., Cinar M., Bintas, E.,
Çoven, F. and Atik, H. 2012. Performance and egg quality of aged laying hens fed diets supplemented with meat and bone meal or oyster shell meal. S. Afr. J. Anim. Sci. 42:74-82.

Chong, C. H., Zulkifli, I. and Blair, R. 2008. Effects of dietary inclusion of palm kernel cake and palm oil, and enzyme supplementation on performance of laying hens. Asian-Aust. J. Anim. Sci. 21:1053-1058.

Ebeid, T. A. 2011. The impact of incorporation of n-3 fatty acids into eggs on ovarian follicular development, immune response, antioxidative status and tibial bone characteristics in aged laying hens. Animal. 5:1544-1562.

Garlich, J., Brake, J., Parkhurst, C. R., Thaxton, J. P. and Morgan, G. W. 1984. Physiological profile of aged layers during one production year, molt and postmolt: Egg production, egg shell quality, liver, femur, blood parameters. Poult. Sci. 63:339-343.

Hanafy, M. 2010. Effect of dietary inulin supplementation on intestinal calcium and phosphorus absorption and egg shell quality in Bandarah laying hens. Egypt. Poult. Sci. 30:799-811.

Lee, E. N., Sunwoo, H. H., Menninen, K. and Sim, J. S. 2002. In vitro studies of chicken egg yolk antibody (IgY) against Salmonella enteritidis and Salmonella typhimurium. Poult. Sci. 81:632-641.

Li. F., Xu, M., Shan, S., Hu, W., Zhang, Y. Y. and Li, Y. H. 2011. Effect of daily feed intake in laying period on laying performance, egg quality and egg composition of genetically fat and lean lines of chickens. Br. Poult. Sci. 52:163-168.

Li, Y., Chen, X., Chen, y., Li, Z. and Cao, Y. 2010. Effects of $\beta$ mannanase expressed by Pichia pastoris in corn-soybean meal diets on broiler performance, nutrient digestibility, energy utilization and immunoglobulin levels. Anim. Feed Sci. Technol. 159:59-67.

Lin, H., Jiao, H. C., Buyse, J. and Decuypere, E. 2006. Strategies for preventing heat stress in poultry. World's Poult. Sci. J. 62:71-85.

Mehri, M., Adibmoradi, M., Samie, A. and Shivazad, M. 2010. Effects of $\beta$-mannanase on broiler performance, gut morphology and immune system. Afr. J. Biotechnol. 9:6221-6228.

Meng, F., Slominski, A., Nyachoti, M., Campbell, D. and Guenter, W. 2005. Degradation of cell wall polysaccharides by combinations of carbohydrase enzymes and their effect on nutrient utilization and broiler chicken performance. Poult. Sci. 84:37-47.

Monira, K. N., Salahuddin, M. and Miah, G. 2003. Effect of breed and holding period on egg quality characteristics of chickens. Int. J. Poult. Sci. 2:261-263.

Moreki, J. C., Van Der Merwe, H. J. and Hayes, J. P. 2011. 
Lee et al.; Dietary ß-Mannanase and Palm Kernel Meal PKM in Old Aged Laying Hens

Influence of dietary calcium levels on bone development in broiler breeder hens. Online J. Anim. Feed Res. 1:77-85.

Ong, A. S. and Goh, S. H. 2002. Palm oil: a healthful and cost-effective dietary component. Food Nutr. Bull.23:11-22.

Pavlik, A., Lichovnikova, M. and Jelinek, P. 2009. Blood plasma mineral profile and qualitative indicators of the eggshell in laying hens in different housing systems. Acta Vet. Brno. 78:419-429.

Pereira, F., do Vale, M., Zevolli, R. and Salgado, D. 2010. Estimating mortality in laying hens as the environmental temperature increases. Braz. J. Poult. Sci. 12:265-271.

Perez, J. F., Gernat, A. G. and Murillo, J. G. 2000. The effect of different levels of palm kernel meal in layer diets. Poult. Sci. 79:77-79.

Rahman, M. S., Akbar, M. A., Islam, K. S., Iqbal, A. and Assaduzzaman, M. 2010. Effect of dietary inclusion of palm oil on feed consumption, growth performance and profitability of broiler. Bang. J. Anim. Sci. 39:176-182.

Ramirez, M., Amate, L. and Gil, A. 2001. Absorption and distribution of dietary fatty acids from different sources. Early Human Dev. 65:S95-S101.

Roberts, J. and Ball, W. 2004. Diet type, apparent metabolizable energy and digesta viscosity in laying hens of two different ages. Proc. Aust. Poult. Sci. Sym. 16:59-62.

SAS. 2004. SAS User's Guide: Statistics. Version 6.04 Ed. Cary, North Carolina, USA: SAS Institute Inc.

Shahidi, F. 2005. Bailey's Industrial Oil and Fat Products. $6^{\text {th }}$ Ed. Wiley-Interscience. NY. ISBN 0-471-38460-7.

Soltan, M. A. 2008. Effect of organic acid supplementation on egg production, egg quality, and some blood serum parameters in laying hens. Intl. J. Poult. Sci. 7:613-621.

Sundu, B., Kumar, A. and Dingle, J. 2006. Palm kernel meal in broiler diets: effect on chicken performance and health. World's Poult. Sci. J. 62:316-325.

Świątkiewicz, S., Koreleski, J. and Arczewska, A. 2010. Laying performance and eggshell quality in laying hens fed diets supplemented with prebiotics and organic acids. Czech J. Anim. Sci. 55:294-306

Tuleun, C. D., Carew, S. N. and Ajiji, I. 2008. Feeding value of velvet beans (Mucuna utilis) for laying hens. Livest. Res. Rural Dev. 20: \#81. http://www.lrrd.org.

Van der Klis, J. D., Kwakernaak, C. W. and De Wit, W. 1995. Effects of endoxylanase addition to wheat-based diets on physico-chemical chyme conditions and mineral absorption in broilers. Anim. Feed Sci. Technol. 51:15-27.

Van Krimpen, M., Kwakkel, P., Van Der Peet-Schwering, M., Den Hartog, A. and Verstegen, W. 2011. Effects of dietary energy concentration, non-starch polysaccharide concentration, and particle sizes of nonstarch polysaccharides on digesta mean retention time and gut development in laying hens. Br. Poult. Sci. 52:730-741.

Wu, G., Bryant, M. M., Voitle, R. A. and Roland, D. A. Sr. 2005. Effects of beta-mannanase in corn-soy diets on commercial leghorns in second-cycle hens. Poult. Sci. 84:894-897.

Zanu, H. K., Abangiba, J., Arthur-Badoo, W., Akparibo, A. D. and Sam, R. 2012. Laying chickens' response to various levels of palm kernel cake in diets. Intl. J. Livest. Prod. 3:12-16.

Zita, L., Ledvinka, Z., Tumova, E. and Klesalova, L. 2012. Technological quality of eggs in relation to the age of laying hens and Japanese quails. R. Bras. Zootec. 41:2079-2084.

Zou, X. T., Qiao, X. J. and Xu, Z. R. 2006. Effect of beta-mannanase (Hemicell) on growth performance and immunity of broilers. Poult. Sci. 85:2176-2179.

(Received Apr. 4, 2013; Revised Apr. 19, 2013; Accepted Apr. 19, 2013) 